\title{
PENGARUH UKURAN PERUSAHAAN, KEPEMILIKAN INSTITUSIONAL, KOMISARIS INDEPENDEN DAN LEVERAGE TERHADAP KINERJA KEUANGAN. \\ (Studi Empiris pada Bank Umum Syariah yang terdaftar di OJK Indonesia tahun 2015-2019)
}

\author{
Ernawati, Suryo Budi Santoso \\ Program Studi Akuntansi S1, Univesitas Muhammadiyah Purwokerto \\ suryobs@gmail.com
}

\begin{abstract}
ABSTRAK
The purpose of this study was to examine the effect of company size, institutional ownership, indepnendent commissioners and leverage on financial performance as proxied by ROA (Return on Asset). The independent variables in this study are company size, institutional ownership, independent commissioners and leverage, while the dependent variable is financial performance (ROA). The population in this study were Islamic commercial bank companies in the 2015-2019 period. The data collection technique used was purposive sampling, in order to obtain a sample of 14 companies with 52 data that match the criteria. The results of this study indicate that the variables of company size, institutional ownership, independent commissioners do not have a positive effect on financial performance. However, another variable, namely leverage, has a negative effect on financial performance.
\end{abstract}

Keywords: Company size, institutional ownership, independent commissioners, leverage, financial performance.

\begin{abstract}
ABSTRAK
Tujuan dari penelitian ini adalah untuk menguji pengaruh ukuran perusahaan, kepemilikan institusional, komisaris independen dan leverage terhadap kinerja keuangan yang diproksikan dengan ROA (Return on Asset). Variabel independen dalam penelitian ini adalah ukuran perusahaan, kepemilikan institusional, komisaris independen dan leverage sedangkan variabel dependen adalah kinerja keuangan (ROA). Populasi dalam penelitian ini adalah perusahaan bank umum syariah pada periode 2015-2019. Teknik pengumpulan data yang digunakan adalah purposive sampling, sehingga diperoleh sampel sebanyak 14 perusahaan dengan 52 data yang sesuai kriteria. Hasil penelitian ini menunjukkan bahwa variabel ukuran perusahaan, kepemilikan institusional, komisaris independen tidak berpengaruh positif terhadap kinerja keuangan. Namun, variabel lainnya yaitu leverage berpengaruh negatif terhadap kinerja keuangan.
\end{abstract}

Kata kunci: Ukuran perusahaan, kepemilikan institusional, komisaris independen, leverage, kinerja keuangan. 


\section{PENDAHULUAN}

Pada bulan Oktober 2019 pertumbuhan perbankan di Indonesia semakin membaik. Berdasarkan data Otoritas Jasa Keuangan (OJK) bulan Oktober 2019 market share perbankan syariah Indonesia mampu menembus angka 6\% atau sekitar Rp513 triliun, jauh lebih baik dibandingkan pada tahun 2014 yang hanya menembus market share sebesar 5\% (Santoso, 2014). Faktor pendukung terbesar dari pencapaian market share ini adalah karena meningkatkan pertumbuhan aset perbankan syariah pada unit BUS dan UUS sebesar 10,15\% secara dibandingkan sebelumnya menjadi Rp499,98 triliun. Bank syariah mampu merealisasikan pertumbuhan di angka 10,52\% dibanding sebelumnya menjadi Rp345,28 triliun dan kenaikan dana pihak ketika (DPK) menjadi Rp402,36 triliun. Saat ini, market share perbankan syariah Indonesia dikuasai oleh 14 Bank Umum Syariah (BUS) atau sekitar 65\%, sedangkan 32\% market share perbankan syariah di kuasai 20 Unit Usaha Syariah (UUS) dan sisanya di kuasai oleh 165 Bank Pembiayaan Rakyat Syariah (BPRS).

Berdasarkan kondisi yang sudah dijelaskan di atas perkembangan bank syariah di Indonesia semakin meningkat. Kesuksesan perusahaan bisa diukur dengan kinerja keuangan pada perbankan tersebut. Kinerja keuangan bisa bernilai positif maupun negatif tergantung bagaimana perusahaan tersebut menjalankan aktivitas bisnisnya. Agar perusahaan berjalan dengan baik perusahaan harus menyusun strategi dengan baik, kita juga dapat mengetahui integritas informasi laporan keuangan melalui ukuran perusahaan, kita juga bisa mengukur seberapa besar aktiva yang di miliki perusahaan dari modal atau hutang, kita juga dapat monitoring manajemen sehingga dapat mendorong peningkatan pengawasan yang lebih baik lagi, kita juga dapat mengurangi kecurangan dalam laporan keuangan terhadap manajemen. Hal ini dikarenakan perusahaan bukanlah entitas yang hanya beroperasi untuk kepentingan sendiri, namun harus memberikan manfaat bagi stakeholders-nya (Chairi dan Ghozali, 2007).

Menurut Isbanah (2018) kinerja keuangan merupakan bagian yang sangat penting dalam mencapai tujuan perusahaan, banyak faktor yang dapat mempengaruhi kinerja keuangan suatu perusahaan. Kinerja keuangan perusahaan dapat memerikan gambaran bagi investor mengenai tingkat keuntungan yang akan didapat dimasa yang akan mendatang atau dengan orientasi jangka panjang. (Kurniati dan Saifi, 2018).

Berdasarkan penjelasaan di atas dapat disimpulkan ada beberapa faktor yang dapat mempengaruhi kinerja keuangan perbankan, diantaranya yaitu ukuran perusahaan, kepemilikan institusional, komisaris independen dan leverage. Faktor pertama yang mempengaruhi kinerja keuangan perbankan yaitu ukuran perusahaan. Ukuran perusahaan menggambarkan besar dan kecilnya suatu perusahaan (Seftiane, 2011). Ukuran perusahaan 
dianggap mampu mempengaruhi kinerja keuangan perusahaan, karena semakin besar ukuran perusahaan atau skala perusahaan maka akan semakin mudah pula perusahaan memperoleh sumber pendanaan baik yang bersifaat internal maupun eksternal (Nugraha, 2014). Menurut Theacini dan Wisadha (2014) serta Sayekti dan Santoso (2020) menyatakan bahwa ukuran perusahaan berpengaruh positif terhadap kinerja keuangan. Hal tersebut bertentangan dengan Puspitari dan Hartono (2016) serta Wardani dan Rudolfus (2017) yang menemukan bahwa ukuran perusahaan berpengaruh negatif terhadap kinerja keuangan.

Faktor yang kedua yang mempengaruhi kinerja keuangan perbankan yaitu kepemilikan institusional. Kepemilikan institusional adalah kepemilikan saham perusahaan oleh industri keuangan seperti perusahaan asuransi, bank, dana pensiun, dan investment banking (Siregar dan Utama, 2005). Kepemilikan Institusional juga memiliki peran penting dalam melakukan fungsi monitoring manajemen sehingga dapat mendorong peningkatan pengawasaan yang lebih optimal (Aini dkk, 2017). Hal ini juga menunjukan bahwa fungsi kontrol dari pemilik sangat menentukan dalam meningkatkan kinerja perusahaan. Widyati (2013) dalam penelitiannya menyatakan kepemilikan institusional berpengaruh positif terhadap kinerja keuangan. Hasil penelitian ini sesuai dengan hasil penelitian yang dilakukan oleh Darwis (2009).

Faktor yang ketiga yang mempengaruhi kinerja keuangan perbankan yaitu komisaris independen. Komisaris independen dapat meningkatkan fungsi pengawasan pada perusahaan adanya dewan komisaris independen dalam perusahaan dapat mengurangi masalah keagenan dan mencegah terjadinya perilaku oportunistik (Candradewi dan Sedana, 2016). Menurut Aini dkk, (2017) proporsi dewan komisaris independen dapat melakukan pengawasan secara lebih baik terhadap manajemen, sehingga dapat mengurangi kecurangan dalam menyajikan laporan keuangan. Hal ini menunjukan pengawasan yang dilakukan oleh komisaris independen mampu mempengaruhi perilaku manajer dalam upaya meningkatkan kinerja perusahaan (Maryanah dan Amilian, 2011). Widyati (2013) dalam penelitiannya menyatakan komisaris independen berpengaruh positif terhadap kinerja keuangan.

Faktor yang terakhir yang mempengaruhi kinerja keuangan perbankan yaitu besarnya leverage. yaitu rasio antara hutang dengan modal sendiri. Rasio ini digunakan untuk mengetahui jumlah dana yang disediakan oleh kreditor dengan pemilik perusahaan sehingga rasio ini berfungsi untuk mengetahui setiap rupiah modal sendiri yang dijadikan jaminan utang. Semakin tinggi rasio ini menunjukan semakin tingginya rasio kegagalan yang mungkin terjadi pada perusahaan, begitu juga sebaliknya apabila semakin rendah rasio ini maka menunjukan rendah pula risiko kegagalan yang mungkin terjadi pada perusahaan (Junaedi, 2015). Menurut 
Erawati (2019), Tambun dan Prabawani (2018) Leverage berpengaruh positif terhadap kinerja perusahaan. Sedangkan menurut Isbanah (2015), Sayekti dan Santoso (2020) Leverage berpengaruh negatif terhadap kinerja keuangan perusahaan.

Penelitian ini diharapkan dapat menjadi referensi yang menjelaskan pengaruh ukuran perusahaan, kepemilikan institusional, komisaris independen dan leverage terhadap kinerja keuangan.

\section{TINJAUAN PUSTAKA DAN PENGEMBANGAN HIPOTESIS}

\section{Teori Enterprise Syariah}

Syariah berarti segala bentuk operasioal perusahaan akan tunduk pada prinsip syariah (Triyuwono, 2012). Selain itu, Triyuwono (2012) mengusulkan apa yang disebut dengan shari'ah enterprise theory. Secara implisit Triyuwono mengutarakan bahwa akuntansi syariah tidak saja sebagai bentuk akuntabilitas (accountability) manajemen terhadap pemilik perusahaan (stockholders), tetapi juga sebagai akuntabilitas kepada stakeholders dan Tuhan. Pada prinsipnya shari'ah enterprise theory bertujuan memberikan bentuk pertanggungjawaban utamanya kepada Allah (vertikal) yang kemudian dijabarkan lagi pada bentuk pertanggungjawaban (horizontal) pada umat manusia dan lingkungan alam. Konsep pertanggungjawaban yang ditawarkan oleh teori ini tidak sekedar pengembangan konsep pertanggungjawaban enterprise theory, namun lebih dari itu sebagai hasil dari premis yang dipakai oleh shari'ah enterprise theory yang memiliki karakter transendental dan teleologikal.

\section{Teori Agency}

Konsep Agency Theory didasari pada permasalahan agensi yang muncul ketika pengurusan suatu perusahaan terpisah dari kepemilikaannya (Nuswandari, 2009). Agency Theory menurut Jansen and Meckling (1976) adalah sebuah kontrak antara manajer (agent) dengan investor (principal). Principal adalah pemegang saham, sedangkan yang dimaksud dengan agen adalah manajemen yang mengelola perusahaan. Jadi intinya hubungan keagenan adalah adanya pemisahaan antara kepemilikan (principal/investor) dan pengendalian (agent/manajer).

\section{Pengaruh Ukuran Perusahaan Terhadap Kinerja Keuangan}

Ukuran perusahaan adalah suatu skala di mana dapat diklarifikasikan besar kecilnya perusahaan menurut berbagai cara antara lain dengan total aset, nilai pasar saham, dan lain lain (Prasetyorini, 2013). Ukuran perusahaan dianggap mampu mempengaruhi nilai perusahaan 
karena semakin besar ukuran atau skala perusahaan maka akan semakin mudah bagi perusahaan dalam memperoleh sumber pendanaan, baik yang bersifat internal maupun eksternal. Besar kecilnya perusahaan akan mempengaruhi kemampuan dalam menanggung risiko yang mungkin timbul dari berbagai situasi yang dihadapi perusahaan. Perusahaan besar memiliki risiko yang lebih rendah dari pada perusahaan kecil. Hal ini dikarenakan perusahaan besar memiliki kontrol yang lebih baik terhadap sumber-sumber pendanaan dari eksternal dibandingkan dengan perusahaan kecil (Ernawati dan Widyawati, 2015), seorang investor akan lebih merespon secara positif terhadap perbankan besar sehingga akan meningkatkan nilai bagi perbankan yang berskala besar.

Menurut teori keagenan ukuran perusahaan berpengaruh terhadap kinerja keuangan perusahaan yang berukuran besar memiliki basis pemegang kepentingan yang lebih luas, sehingga berbagai kebijakan perusahaan besar akan berdampak lebih besar terhadap kepentingan publik dibandingkan perusahaan kecil. Theacini dan Wisadha (2014) serta Sayekti dan Santoso (2020) menyatakan bahwa ukuran perusahaan berpengaruh positif terhadap kinerja keuanga. Berdasarkan uraian tersebut, dapat dirumuskan hipotesis dalam rumusan ini adalah:

\section{$\mathrm{H}_{1}$ : Ukuran perusahaan berpengaruh positif terhadap kinerja keuangan}

\section{Pengaruh Kepemilikan Institusional terhadap Kinerja Keuangan}

Besarnya kepemilikan institusional sangat berpengaruh terhadap kinerja manajemen yaitu dengan memberikan motivasi lebih kuat untuk meningkatkan aktivitas perusahaan sehingga berdampak pada laba yang diperoleh dan dapat meningkatkan kinerja (Prahesti dan Abundanti, 2014). Menurut teori keagenan kepemilikan institusional berpengaruh terhadap kinerja keuangan. Apabila dalam perusahaan terdapat saham yang dimiliki oleh institusi maka manajemen akan bertindak sesuai dengan aturan yang berlaku, kepemilikan institusional akan melakukan hal tersebut dikarenakan, pengawasan terhada cara kerja manajemen perusahaan dalam mengoprasionalkan perusahaan sehingga manajemen akan merasa mendapat tekanan dan berusaha untuk melalukan yang terbaik untuk meningkatkan kinerja perusahaan. Widyati (2013) dalam penelitiannya menyatakan kepemilikan institusional berpengaruh positif terhadap kinerja keuangan. Hasil penelitian ini sesuai dengan hasil penelitian yang dilakukan oleh Darwis (2009). Berdasarkan uraian tersebut, dapat dirumuskan hipotesis dalam rumusan ini adalah:

\section{H2: Kepemilikan institusional berpengaruh positif terhadap kinerja keuangan}




\section{Pengaruh Komisaris Independen terhadap kinerja Keuangan.}

Adanya dewan komisaris independen, maka kepentingan pemegang saham, baik mayoritas maupun minoritas tidak diabaikan karena komisaris independen lebih bersikap netral terhadap keputusan yang dibuat oleh manajer (Puspitasari dan Ernawati, 2010). Komisaris independen dapat meningkatkan pengawasan pada perusahaan adanya dewan komisaris tersebut dapat meminimalisir masalah yang ada pada keagenan. Tugas secara umum dewan komisaris ditugaskan dan diberi tanggung jawab atas pengawasan kualitas informasi yang terkandung dalam laporan keuangan. Widyati (2013) dan Wulandari (2016) menyatakan komisaris independen berpengaruh positif terhadap kinerja keuangan. Hasil penelitian ini sesuai dengan Hapsoro (2008). Berdasarkan uraian tersebut, dapat dirumuskan hipotesis dalam rumusan ini adalah:

\section{H3: Komisaris independen berpengaruh positif terhadap kinerja keuangan.}

\section{Pengaruh Leverage terhadap Kinerja keuangan}

Menurut Munawir (2004) Leverage merupakan kemampuan perusahaan untuk memenuhi seluruh kewajiban keuangan perusahaan apa bila dilikuidasi baik jangka pendek maupun jangka panjang. Dari sudut pandang manajemen keuangan, rasio leverage keuangan membawa implikasi penting dalam pengukuran risiko finansial perusahaan. Semakin besar utang suatu perusahaan akan berpengaruh terhadap laba, karena biaya bunga semakin banyak. Semakin besar rasio leverage menunjukan posri penggunaan utang dalam membiayai investasi pada aset semakin besar, yang berarti risiko keuangan perusahaan meningkat, dan sebaliknya. Kreditur secara umum lebih menyukai jika rasio utang yang dimiliki perusahaan lebih rendah karena semakin rendah rasio utang maka semakin tinggi tingkat pendanaan perusahaan yang disediakan oleh pemegang saham dan semakin besar perlindungan bagi kreditor atas risiko tidak terbayarnya utang (Hery, 2017). Menurut Isbanah (2015), leverage berpengaruh negatif terhadap kinerja perusahaan. Demikian juga Sayekti dan Santoso (2020) menyatakan bahwa leverage berpengaruh negatif terhadap kinerja keuangan perusahaan. Berdasarkan uraian tersebut, dapat dirumuskan hipotesis dalam rumusan ini adalah:

\section{H4: Leverage berpengaruh negatif terhadap kinerja keuangan.}

\section{METODE PENELITIAN}

Penelitian ini merupakan jenis penelitian kuantitatif. Penelitian kuantitatif adalah penelitian yang dilakukan dengan mengumpulkan data yang berupa angka. Data berupa angka 
tersebut kemudian diolah dan dianalisis untuk mendapatkan suatu informasi ilmiah dibalik angka-angka tersebut (Martono, 2011).

Populasi dalam penelitian ini yaitu 14 Bank Umum Syariah yang ada di Otoritas Jasa Keuangan (OJK). Jenis data yang digunakan dalam penelitian ini adalah data sekunder yang bersumber dari laporan keuangan tahunan bank umum syariah periode 2015-2019. Data laporan keuangan diperoleh dari website resmi OJK atau www.ojk.go.id. Pada penelitian ini teknik pengumpulan datanya menggunakan metode dokumentasi dengan mencatat data tersebut yang berhubungan dengan penelitian. Data pendukung lainnya diperoleh distudi pustaka cara mengumpulkan data dengan membaca buku atau jurnal-jurnal ilmiah yang digunakan dalam penelitian ini dengan menggunakan kriteria pengambilan sampel sebagai berikut:

a. Sektor bank umum syariah yang telah terdaftar di (www.ojk.go.id) selama periode 20152019.

b. Laporan keuangan yang tidak memiliki rugi karena apabila rugi akan mempengaruhi informasi yang dimiliki oleh perusahaan.

c. Laporan keuangan yang memiliki data lengkap untuk variabel ukuran perusahaan, kepemilikan institusional, komsaris independen, leverage dan kinerja keuangan.

\section{Definisi Operasional dan Pengukuran Variabel}

\section{Kinerja Keuangan}

Rasio yang digunakan dalam penelitian ini adalah Return On Assets (ROA). Rasio ini untuk mengukur seberapa besar jumlah laba bersih dapat dihasilkan oleh perusahaan dengan memanfaatkan aset yang dimiliki perusahaan (Hery, 2015). ROA menunjukan kemampuan perusahaan dalam melakukan efesiensi dalam menggunakan aset guna mendapatkan keuntungan. Variabel yang digunakan dalam penelitian ini mengacu pada penelitian (Pratama, 2016). Indikator pengukuran ROA, sebagai berikut:

$$
\text { ROA }=\frac{\text { Laba bersih setelah pajak }}{\text { Total Aset }} \times 100 \%
$$

\section{Ukuran Perusahaan}

Ukuran perusahaan adalah skala yang menunjukkan besar kecilnya perusahaan (Yuliawati, 2015). Ukuran perusahaan adalah suatu skala yang mengukur besar kecilnya 
perusahaan. Semakin besar ukuran perusahaan maka tuntutan stakeholders atas manfaat keberadaan perusahaan tersebut cenderung lebih besar (Yuliawati, 2015). Ukuran perusahaan dalam penelitian ini mengacu pada pendapat Riyanto (2012) dimana ukuran perusahaan dirpoksi dengan nilai logaritma natural dari total aset. Secara sistematis dapat dirumuskan sebagai berikut:

$$
\mathrm{UP}=\operatorname{Ln}(\text { Total Aset })
$$

\section{Kepemilikan Institusional}

Kepemilikan institusional merupakan saham perusahaan yang dimiliki oleh institusi atau lembaga (perusahaan asuransi, bank, perusahaan investasi dan kepemilikan institusi lain) (Raharjo, 2014). Fadilah (2017) semakin banyak kepemilikan institusional maka semakin bagus kinerja perusahaan. Hal ini disebabkan investor institusional mayoritas memiliki kecenderungan untuk berkompromi atau berpihak kepada manajemen dan mengabaikan kepentingan pemegang saham minoritas sehingga disaat kepemilikan institusional meningkat maka akan menurunkan kinerja perusahaan.

$$
\text { INST }=\frac{\text { Jumlah saham pihak institusi }}{\text { Total saham yang beredar }} \times 100 \%
$$

\section{Komisaris Independen}

Menurut Candradewi dan Sedana (2016) dewan komisaris independen dapat membantu perusahaan menghindari ancaman-ancaman dari luar sehingga tetap bisa mempertahankan sumber daya perusahaan agar mendapatkan keuntungan yang lebih, yang nantinya dapat meningkatkan kinerja keuangan (ROA). Komisaris independen adalah anggota dewan komisaris yang tidak terafiliasi dengan direksi, anggota dewan komisaris lainnya dan pemegang saham pengendali, serta bebas dari hubungan bisnis atau hubungan lainnya yang dapat mempengaruhi kemampuannya untuk bertindak independen atau bertindak semata mata demi kepentingan perusahaan. Jumlah komisaris independen dalam satu perusahaan ditetapkan paling sedikit 30 persen dari jumlah seluruh komisaris (Susilo, 2010).

Dalam penelitian ini rumus yang digunakan untuk mengukur komisaris independen sebagai berikut (Julianti, 2015):

$$
\text { INDP }=\frac{\text { Jumlah komisarit independen }}{\text { Jumlah anggota komisaris }} \times 100 \%
$$

\section{Leverage}


Leverage merupakan rasio yang digunakan untuk mengukur sejauh mana aktiva perusahaan dibiayai dengan utang. Semakin besar rasio ini, akan semakin tidak menguntungkan bagi bank (kreditor) karena akan semakin besar rasio yang ditanggung atas kegagalan yang mungkin terjadi di perusahaan (Kasmir, 2011). Pengukuran rasio leverage diukur dengan menggunakan DER yang dirumuskan sebagai berikut:

$$
\text { DER }=\frac{\text { Total Hutang }}{\text { Total Ekuitas }} \times 100 \%
$$

\section{HASIL DAN PEMBAHASAN}

\section{Statistik Deskriptif}

Ukuran perusahaan memiliki nilai minimum sebesar 27,30, nilai maksimum sebesar 32,35, nilai mean sebesar 30,2980 dengan standar deviasi sebesar 1,14569. Kepemilikan institusional memiliki nilai minimum sebesar 70,00, nilai maksimum sebesar 100,00, nilai mean sebesar 96,8509 dengan standar deviasi sebesar 6,50056. Kepemilikan institusional memiliki nilai minimum sebesar 25,00, nilai maksimum sebesar 100,00, nilai mean sebesar 64,2949 dengan standar deviasi sebesar 13,33066. Leverage memiliki nilai minimum sebesar 20,13, nilai maksimum sebesar 349,64, nilai mean sebesar 139,1277 dengan standar deviasi sebesar 84,54536. Kinerja keuangan memiliki nilai minimum sebesar 0,02, nilai maksimum sebesar 10,80, nilai mean sebesar 1,3790 dengan standar deviasi sebesar 2.38248.

\section{Uji Normalitas}

Berikut hasil uji normalitas dengan menggunakan uji one sample Kolmogrov-Smirnov menunjukan bahwa data berjumlah 52 nilai Asymp. Sig. (2-tailed) sebesar 0,323 < dari nilai 0,05 sehingga dapat disimpulkan bahwa variabel dalam penelitian ini berdistribusi normal.

\section{Uji Multikolonieritas}

Berdasarkan hasil uji multikolinearitas menunjukan nilai tolerance $<1,00$ dan nilai VIF $<10,00$ untuk setiap variabel. Nilai tolerance yang dihasilkan untuk variabel ukuran perusahaan, kepemilikan institusional, komisaris independen dan leverage adalah sebesar 0,433; 0,893; 0,957; dan 0,453 sedangkan nilai VIF yang dihasilkan untuk variabel ukuran perusahaan, kepemilikan institusional, komisaris independen dan leverage adalah 2,312; 1,119; 1,045; dan 2,207. Berdasarkan hasil uji multikolinieritas tersebut, dapat disimpulkan bahwa semua variabel dalam penelitian ini tidak terjadi gejala multikolinearitas.

\section{Uji Heterokesdatisitas}


Berdasarkan hasil diatas menggunakan uji glejser menunjukan bahwa variabel ukuran perusahaan, kepemilikan institusional, komisaris independen dan leverage memiliki nilai signifikan berada diatas tingkat kepercayaan 0,05. Jadi model regresi tidak mengandung gejala heteroskedastisitas.

\section{Uji Autokorelasi}

Berdasarkan tabel diatas nilai Durbin-Watson yang diperoleh adalah 0,943. Karena nilai DW berada diantara -2 dan 2 maka dapat disimpulkan tidak terdapat gejala autokorelasi (Santoso, 2012).

\section{Analisis Regresi Linier Berganda}

Hasil regresi yang menunjukkan ukuran perusahaan, kepemilikan institusional, komisaris independen dan leverage terhadap kinerja keuangan, dapat dilihat pada tabel dibawah ini:

Model Regresi dan Hasil Uji t

\begin{tabular}{|c|c|c|c|c|c|}
\hline \multirow{2}{*}{ Variabel } & \multicolumn{2}{|c|}{ Unstandardized coefficient } & \multirow{2}{*}{$\begin{array}{c}\text { Standardized Coefficients } \\
\text { Beta }\end{array}$} & \multirow{2}{*}{$\mathbf{t}$} & \multirow{2}{*}{ Sig. } \\
\hline & $\mathbf{B}$ & Std. Error & & & \\
\hline Konstanta & $-46,69$ & 32,63 & & $-1,43$ & 0,16 \\
\hline UP & 13,64 & 8,00 & 0,35 & 1,71 & 0,09 \\
\hline INST & 1,61 & 2,84 & 0,08 & 0,57 & 0,57 \\
\hline INDP & $-0,35$ & 0,89 & $-0,05$ & $-0,39$ & 0,69 \\
\hline LEV & $-1,36$ & 0,42 & $-0,65$ & $-3,26$ & 0,01 \\
\hline
\end{tabular}

Sumber: Output SPSS diolah tahun, 2021

Berdasarkan pada hasil koefisien regresi diatas, maka dapat dibuat model persamaan regresi linear berganda sebagai berikut :

$\mathrm{KK}=-46,698+13,643 \mathrm{UP}+1,614 \mathrm{INST}-0,350 \mathrm{INDP}-1,365 \mathrm{LEV}+\mathrm{e}$

\section{Hasil Uji Koefisien Determinan $\left(\mathbf{R}^{2}\right)$}

Hasil uji koefisien determinan $\left(\mathrm{R}^{2}\right)$ dapat dilihat pada tabel berikut:

\section{Hasil Uji Koefisien Determinasi $\left(\mathbf{R}^{2}\right)$}

\begin{tabular}{cccc}
\hline $\mathrm{R}$ & $\mathrm{R}$ Square & Adjusted R Square & Std. Error of the Estimate \\
\hline $0,449^{\mathrm{a}}$ & 0,202 & 0,134 & 1,38477 \\
\hline
\end{tabular}

Berdasarkan hasil uji koefisien dereminasi diperoleh nilai Adjusted $R$ Square sebesar 0,134 . Nilai ini menunjukkan bahwa variabel dependen yaitu kinerja keuangan dapat dijelaskan oleh variabel independen yaitu ukuran perusahaan, kepemilikan institusional, komisaris independen, dan leverage sebesar 0,134 atau 13,4\%, sisanya dijelaskan oleh variabel lain diluar model penelitian.

\section{Uji Model (F)}


Uji statistik F pada dasarnya menunjukan apakah semua variabel independen atau bebas yang dimasukan dalam model terhadap variabel dependen/terikat (Ghozali, 2018). Sesuai tidaknya model pada penelitian ini dilihat dari kinerja keuangan dari $\mathrm{F}$ rasio seluruh variabel pada taraf uji $\alpha=0,05$, uji $\mathrm{F}$ dapat dilihat dapat dilihat dalam tabel sebagai berikut:

Hasil Uji F

\begin{tabular}{lccccc}
\hline \multicolumn{1}{c}{ Model } & Sum of Squares & Df & Mean Square & F & Sig. \\
\hline Regression & 22,77 & 4 & 5,69 & 2,97 & $0,03^{\text {b }}$ \\
Residual & 90,13 & 47 & 1,92 & & \\
Total & 112,89 & 51 & & & \\
\hline
\end{tabular}

Sumber : Output SPSS diolah tahun, 2021

Berdasarkan hasil uji F diketahui bahwa nilai signifikansi yang diperoleh sebesar 0,029 yang berarti bahwa nilai signifikansi tersebut lebih kecil dari nilai signifikansi yang digunakan yaitu 0,05 atau $0,029<0,05$, maka dapat disimpulkan bahwa model regresi dalam penelitian ini dapat menjelaskan hubungan antara variabel independen yaitu ukuran perusahaan, kepemilikan institusional, komisaris independen dan leverage terhadap kinerja keuangan.

\section{Uji t}

Uji t dapat dilakukan dengan melihat nilai kinerja keuangan signifikan t masing-masing variabel yang terdapat output hasil regresi menggunakan SPSS. Jika nilai kinerja keuangan signifikan t lebih kecil dari 0,05 maka dapat dikatakan bahwa ada pengaruh yang kuat antara variabel independen dengan variabel dependen (Ghozali, 2018).

\section{Hasil Pengujian Hipotesis Pertama}

Berdasarkan hasil uji hipotesis diperoleh hasil bahwa ukuran perusahaan tidak berpengaruh positif terhadap kinerja keuangan. Hasil penelitian ini sesuai dengan Isbanah (2015), Haryati dan Widyarti (2016) Erawati dan Wahyuni (2019) yang menyatakan bahwa ukuran perusahaan tidak berpengaruh terhadap kinerja keuangan. Hasil ini dapat terlihat pada hasil statistik deskriptif yang memiliki nilai rata-rata ukuran perusahaan sebesar 30,2980. Dan rata-rata kinerja keuangan sebesar 1,3790. Data diatas menunjukan semakin tinggi ukuran perusahaan yang dimiliki perusahaan maka tidak menjamin kinerja keuangannya juga tinggi. Hasil penelitian ini tidak dapat membuktikan teori agency Jansen and Meckling (1976) perusahaan yang berukuran besar memiliki basis pemegang kepentingan yang lebih luas, sehingga berbagai kebijakan perusahaan besar akan berdampak lebih besar terhadap kepentingan publik dibandingkan perusahaan kecil. Menurut Astuti dan Zuhrotun (2007) perusahaan dengan total asset yang besar mencerminkan kemampuan perusahaan. Perusahaan yang besar sudah mapan biasanya kondisi keuangannya juga sudah stabil serta ukuran 
perusahaan yang besar dapat meningkatkan skala ekonomi. Berdasarkan pernyataan tersebut dapat disimpulkan bahwa semakin besar ukuran bank maka semakin bagus kinerja bank.

\section{Hasil Pengujian Hipotesis Kedua}

Berdasarkan hasil uji hipotesis diperoleh hasil bahwa kepemilikan institusional tidak berpengaruh positif terhadap kinerja keuangan. Hasil penelitian ini mendukung penelitian yang dilakukan oleh Wardani dan Rudolfus (2016) serta Erawati dan Wahyuni (2019) yang menyatakan bahwa kepemilikan institusional tidak berpengaruh positif terhadap kinerja keuangaan perusahaan. Hasil ini dapat terlihat pada hasil statistik deskriptif yang memiliki nilai rata-rata kepemilikan institusional sebesar 96,8509. Dan rata-rata kinerja keuangan sebesar 1,3790. Data diatas menunjukan bahwa tinggi rendahnya kepemilikan institusional, maka tidak menjamin kinerja keuangannya juga tinggi.

Kepemilikan institusional tidak selalu menjadi pendorong adanya peningkatan pengawasan yang lebih optimal pada kinerja keuangan. Meskipun di sebuah perusahaan kepemilikan institusional besar dan memicu banyak kontrol dari pihak eksternal yang besar pula namun jika manajemen perusahaan tidak melakukan kewajibannya secara baik maka kinerja keuangan perusahaan juga tidak akan mengalami peningkatan, bahwa dalam kepemilikan modal saham perusahaan, kepemilikan institusional tidak memberikan pengaruh yang signifikan terhadap kinerja keuangan perusahaan. Hal tersebut bisa saja disebabkan karena kepemilikan insitusional akan membuat kinerja perusahaan terikat untuk memenuhi target laba invesor, sehingga cenderung terjadi manipulasi laba (Jati, 2009).

Hasil penelitian ini tidak dapat membuktikan teori agency Jansen and Meckling (1976) karena kepemilikan institusional berpengaruh terhadap kinerja keuangan. Apabila dalam perusahaan terdapat saham yang dimiliki oleh institusi maka manajemen akan bertindak sesuai dengan aturan yang berlaku, kepemilikan institusional akan melakukan hal tersebut dikarenakan, pengawasan terhadap cara kerja manajemen perusahaan dalam mengoperasionalkan perusahaan sehingga manajemen akan merasa mendapat tekanan dan berusaha untuk melakukan yang terbaik untuk meningkatkan kinerja perusahaan.

\section{Hasil Pengujian Hipotesis Ketiga}

Berdasarkan hasil uji hipotesis diperoleh hasil bahwa komisaris independen tidak berpengaruh positif terhadap kinerja keuangan. Hasil penelitian ini mendukung penelitian yang dilakukan oleh Theacini dan Wisadha (2014) serta Darwis (2009) yang menyatakan bahwa komisaris independen tidak berpengaruh positif terhadap kinerja keuangan perusahaan.

Hasil ini dapat terlihat pada hasil statistik deskriptif yang memiliki nilai rata-rata komisaris independen sebesar 64,2949. Dan rata-rata kinerja keuangan sebesar 1,3790. Data 
diatas menunjukan bahwa tinggi rendahnya komisaris independen, maka tidak menjamin kinerja keuangannya juga tinggi.

Penyebab variabel komisaris independen tidak berpengaruh terhadap kinerja keuangan perusahaan karena keberadaan komisaris independen dalam perusahaan yang diobservasi dimungkinkan hanyalah bersifat formalitas untuk memenuhi regulasi saja. Sehingga keberadaan komisaris independen ini tidak untuk menjalankan fungsi monitoring yang baik dan tidak menggunakan independensinya untuk mengawasi kebijakan direksi. Jumlah komisaris independen tidak menjamin keefektifan dalam menjalankan tanggung jawabnya mengelola perusahaan. Hal ini mengindikasikan bahwa adanya komisaris independen dalam perusahaan dinilai belum mampu memberikan dampak yang baik terutama dalam tugasnya untuk melakukan pemantauan atau pengawasan terhadap manajer perusahaan sehingga para pelaku pasar belum sepenuhnya mempercayai kinerja komisaris independen dalam perusahaan. pengawasan yang seharusnya dilakukan oleh komisaris independen belum bisa dijalankan secara maksimal terutama dalam mencegah terjadinya pekerjaan yang merugikan perusahaan.

Hasil penelitian ini tidak dapat membuktikan teori agency. Komisaris independen dapat meningkatkan pengawasan pada perusahaan adanya dewan komisaris tersebut dapat meminimalisir masalah yang ada pada keagenan. Tugas secara umum dewan komisaris ditugaskan dan diberikan tanggungjawab atas pengawasan kualitas informasi yang terkandung dalam laporan keuangan.

\section{Hasil Pengujian Hipotesis Keempat}

Berdasarkan hasil uji hipotesis diperoleh hasil bahwa leverage berpengaruh negatif terhadap kinerja keuangan. Hasil penelitian ini mendukung penelitian yang dilakukan oleh Isbanah (2015) serta Erawati dan Wahyuni (2019), Sayekti dan Santoso (2020) yang menyatakan bahwa leverage berpengaruh negatif terhadap kinerja keuangan perusahaan.

Hasil ini dapat terlihat pada hasil statistik deskriptif yang memiliki nilai rata-rata leverage sebesar 139,1277. Dan rata-rata kinerja keuangan sebesar 1,3790. Data diatas menunjukan semakin tinggi leverage yang dimiliki perusahaan maka kinerja keuangan akan menurun. Begitu juga sebaliknya, perusahaan yang memiliki rasio utang rendah, maka kinerja keuangan perusahaan yang diukur dengan ROA semakin tinggi (Isbanah, 2015). Semakin besar suatu utang perusahaan berpengaruh terhadap laba, karena biaya bunga semakin banyak.

Hal ini sesuai dengan teori enterprise syariah (Triyuwono, 2012) yang semakin besar utang yang dimiliki maka harus semakin tinggi pertanggungjawabannya kepada stakeholders melalui kinerja keuanganya. Karena dalam teori enterprise syariah, Allah SWT sebagai sumber 
amanah utama dan sumber daya yang dimiliki para stakeholder, maka leverage sebagai pertanggungjawaban manajemen perbankan syariah tidak hanya untuk para stakeholder saja namun juga sebagai pertanggungjawaban kepada Allah SWT. Semakin tinggi leverage suatu perusahaan maka kinerja keuangannya turun.

\section{Simpulan}

Penelitian ini dimaksudkan untuk mengetahui pengaruh Ukuran Perusahaan, Kepemilikan Institusional, Komisaris Independen dan Leverage terhadap Kinerja Keuangan pada perusahaan Bank Umum Syariah yang terdaftar di Otoritas Jasa Keuaangan pada periode tahun 2015-2019. Berdasarkan hasil pengujian dapat disimpulkan ukuran perusahaan, kepemilikan institusional dan komisaris independen tidak berpengaruh positif terhadap kinerja keuangan. Adapun leverage berpengaruh negatif terhadap kinerja keuangan.

Terdapat keterbatasan bahwa penelitian ini belum berhasil membuktikan pengaruh ukuran perusahaan, kepemilikan institusional dan komisaris independen terhadap kinerja keuangan. Untuk penelitian selanjutnya diharapkan dapat memperluas populasi, bukan hanya Bank Umum Syariah (BUS) tetapi juga memasukkan Unit Usaha Syariah (UUS) dan Bank Pembiayaan Rakyat Syariah (BPRS) sebagai sampel dalam penelitian selanjutnya agar hasil penelitian bisa digeneralisasi. Penelitian selanjutnya juga dapat memperpanjang periode penelitian untuk sampel yang diteliti agar memperoleh hasil penelitian yang lebih baik dan akurat. Penelitian selanjutnya diharapkan dapat menambah variabel yang diduga memiliki pengaruh kuat terhadap kinerja keuangan.

\section{DAFTAR PUSTAKA}

Aini, A. N., Santoso, E. B., \& Isnani, I. (2017). Pengaruh Kepemilikan Institusional, Proporsi Dewan Komisaris Independen, Komite Audit, Struktur Modal, Ukuran Perusahaan Dan Leverage Terhadap Kinerja Keuangan (Studi Pada Perusahaan Manufaktur Sektor Industri Barang Konsumsi yang Terdaftar di BEI Tahun 2011-2015). Journal Of Accounting, Vol. 3 No. 3.

Antonio, Muhammad Syafi'i. 2005. Bank Syariah, Dari Teori ke Praktek. Gema Insani Press: Jakarta.

Arifin, Z. (2005). Hubungan Antara Corporate Governance dan Variabel Pengurang Masalah Agensi. Jurnal Fakultas Hukum UII, Vol. 1. No. 10.

Candradewi, I., \& Sedana, I. B. P. (2016). Pengaruh Kepemilikan Manajerial, Kepemilikan Institusional dan Dewan Komisaris Independen Terhadap Return On Asset. E-Jurnal Manajemen Universitas Udayana. Vol. 5, No. 5. hal: 3163 - 3190.

Chariri dan Ghozali, Achmad. (2007). Teori Akuntansi. Penerbit Andi, Yogyakarta.

Darwis, H. (2009). Corporate governance terhadap kinerja perusahaan. Jurnal Keuangan dan Perbankan, 13(3).

Elisetiawati, E., \& Artinah, B. (2017). Pengaruh Pelaksanaan Good Corporate Governance, Kepemilikan Institusional dan Leverage Terhadap Kinerja Keuangan (Studi Pada 
Industri Perbankan di Bursa Efek Indonesia). Jurnal Manajemen dan Akuntansi, Vol 17, No. 1.

Fadillah, Adil Ridlo. (2017). Analisis Pengaruh Dewan Komisaris Independen, Kepemilikan Manajerial dan Kepemilikan Institusional Terhadap Kinerja Perusahaan yang Terdaftar di LQ45. Jurnal Akuntansi, Fakultas Ekonomi, Universitas Siliwangi, Vol 12, No. 1, Januari-Juni.

Filatotchev, Igor., Lien, Yung-Chih., dan Piesse Jenifer. (2015). Corporate Governance and Performance in Publicly Listed, Family-Controlled Firms: Evidence from Taiwan. Asia Pasific Journal of Management Vol. 22 N.3. ha:257-283.

Hapsoro, Dody, (2018). Pengaruh mekanisme Corporate Governance Terhadap Kinerja Perusahaan: Studi Empiris di Pasar Modal Indonesia. Jurnal Akuntansi dan Manajemen, Vol 19, No. 3.

Isbanah, Y. (2015). Pengaruh ESOP, leverage, and ukuran perusahaan terhadap kinerja keuangan perusahaan di bursa efek Indonesia. Jurnal Riset Ekonomi dan Manajemen, Vol. 15 No. 1, hal 28-41.

Julianti, Defy Kurnia. (2015). Pengaruh Mekanisme Good Corporate Governance Terhadap Nilai Perusahaan Dengan Profitabilitas Sebagai Variabel Intervening. Jurnal Skripsi. Universitas Negeri Semarang.

Juna, J. (2017). Analisis Pengaruh Good Corporate Governance Dan Financial Leverage Terhadap Kinerja Keuangan Bank Umum Syariah Dengan Volume Pembiayaan Sebagai Variabel Moderasi. Jurnal Riset Keuangan Dan Akuntansi, Vol. 1 No. 02.

Kasmir. (2011). Analisis Laporan Keuangan. Edisi 1 Cetakan 4. Jakarta: PT. Raja Grafindo Persada

Khafa, L., \& Laksitoo, H. (2015). Pengaruh CSR, Ukuran Perusahaan, Leverage, dan keputusan investasi pada Kinerja Keuangan Perusahaan dan Nilai Perusahaan. Diponegoro Journal Accountingg, Vol 4. No. 4. Hal: 207-219.

Kurniati, R. A., \& Saifi, M. (2018). Pengaruh Employee Stock Ownership Program (ESOP) Dan Leverage Terhadap Kinerja Keuangan (Studi pada Perusahaan Sektor Perbankan yang Terdaftar Di Bursa Efek Indonesia Tahun 2014-2016). Jurnal Administrasi Bisnis, Vol. 62. No. 2. Hal: 150-157.

Lestari, W. D., \& Yulianawati, I. (2016). Pengaruh Good Corporate Governance dan Leverage Terhadap Kinerja Keuangan (Studi Pada Perusahaan Manufaktur yang Terdaftar di BEI Tahun 2011-2012). Benefit: Jurnal Manajemen dan Bisnis, Vol. 19. No. 2 hal: 127-136.

Ludijanto, S. E. (2014). Pengaruh analisis leverage terhadap kinerja keuangan perusahaan (Studi pada perusahaan property dan real estate yang listing di BEI tahun 20102012). Jurnal Administrasi Bisnis, Vol. 8. No. 1.

Maryanah., dan Amilin. (2011). Pengaruh Corporate Governance dan Kepemilikan Manajerial Terhadap Kinerja Perusahaan (Studi Pada Perusahaan yang Terdaftar di Bursa Efek Jakarta). Jurnal Akuntanbilitas (Online), (http://journal.aktfebuinjkt.ac.id, diakses pada maret 2020).

Mayangsari, L. P. (2015). Pengaruh Good Corporate Governance Dan Kinerja Keuangan Di Indonesia

Munawir, S. (2012). Analisa Informasi Keuangan, Liberty, Yogyakarta.

Nuswandari, Cahyani, (2009). Pengaruh Corporate Gorvenance Perception Index Terhadap Kinerja Perusahaan Pada Perusahaan Yang Terdaftar di Bursa Efek Jakarta. Jurnal Bisnis dan Ekonomi, Vol. 16, No. 2. Hal. 70-84, ISSN: 1412-31.

Santoso, Suryo Budi. 2014. Supporting Factors for Intensification of Islamic Banking in Indonesia. Human and socio-environmental studies. 27(1): 39:55

Santoso, Suryo Budi. 2014. An Overview of Current Banking System in Indonesia: Comparison between Conventional and Islamic Banks. Human and socioenvironmental studies. 28(3): 179-197 
Sayekti, L. M., \& Santoso, S. B. (2020). Pengaruh Ukuran Perusahaan, Debt to Equity Ratio, Debt to Asset Ratio dan Risk Based Capital Terhadap Profitabilitas (Studi Empiris pada Perusahaan Asuransi Umum Unit Usaha Syariah Tahun 2014-2018). Reviu Akuntansi Kontemporer Indonesia, Vol. 1 No. 1.

Sugiyono. 2011. Metode Penelitian Kuantitataif Kualitatif dan $R \&$ D. Bandung: Alfabeta.

Susilo, Budi. 2010. Pengaruh Kepemilikan Manajerial, Proporsi Dewan Komisaris Independen, Jumlah Komite Audit dan Keahlian Komite Audit Terhadap Manajemen Laba. Skripsi Dipublikasikan. Universitas Islam Negri Syarif Hidayatullah.

Suwito, E., \& Herawaty, A. (2012). Analisis pengaruh karakteristik perusahaan terhadap tindakan perataan laba yang dilakukan oleh perusahaan yang terdaftar di Bursa Efek Jakarta.

Syamsudin, L. (2011). Manajemen Keuangan Perusahaan: Konsep Aplikasi dalam Perencanaan, Pengawasan dan Pengambilan Keputusan. Edisi Baru. Jakarta: Rajawali Press.

Talenta, J., Tambunan, A., \& Prabawani, B. (2016). Teguh Erawati, Fitri Wahyuni. 2019. Pengaruh Corporate Governance, Ukuran Perusahaan, Dan Leverage, Terhadap Kinerja Keuangan Perusahaan. Jurnal Akuntansi Pajak Dewantara Vol.1 No. 2 Mei Agustus 2019.

Theacini, Deby Anastasia Meilic, dan I. Gde Suparta Wisadha. 2014. "Pengaruh Good Corporate Governance, Kualitas Laba dan Ukuran Perusahaan pada Kinerja Perusahaan.” E-Jurnal Akuntansi Universitas Udayana (2014): 733-746

Wahyuni, F., \& Erawati, T. (2019). Pengaruh Corporate Governance, Ukuran Perusahaan, dan Leverage Terhadap Kinerja Keuangan Perusahaan di Bursa Efek Indonesia (Studi Kasus Perusahaan Manufaktur yang Terdaftar di Bursa Efek Indonesia Periode 20132017). Jurnal Akuntansi Pajak Dewantara, 1(2), 113-128.

Wardani, D., \& Rudolfus, M. Y. (2017). Dampak Leverage, Kepemilikan Institusional dan Ukuran Perusahaan terhadap Kinerja Perusahaan pada Perusahaan Manufaktur Periode 2011-2015. Jurnal Keuangan dan Perbankan, 13(1), 1-16. 